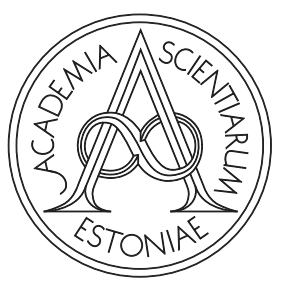

Proceedings of the Estonian Academy of Sciences, 2022, 71, 1, 77-83

https://doi.org/10.3176/proc.2022.1.07

Available online at www.eap.ee/proceedings

COMPUTATIONAL MECHANICS

\title{
Free vibration analysis of tapered Timoshenko beam with higher order Haar wavelet method
}

\author{
This paper is dedicated to the 100th birthday of Professor Ülo Lepik. \\ This study can be considered as a continuation of the research in the area of \\ Haar wavelet methods started by Professor Ülo Lepik \\ Marmar Mehrparvar*, Jüri Majak, Kristo Karjust and Mustafa Arda \\ Department of Mechanical and Industrial Engineering, Tallinn University of Technology, Ehitajate tee 5, 19086 Tallinn, Estonia \\ Received 11 November 2021, accepted 4 January 2022, available online 15 February 2022 \\ (C) 2022 Authors. This is an Open Access article distributed under the terms and conditions of the Creative Commons Attribution 4.0 \\ International License CC BY 4.0 (http://creativecommons.org/licenses/by/4.0).

\begin{abstract}
In the current study, the higher order Haar wavelet method based formulation is developed for the analysis of the free vibrations of the tapered Timoshenko beam. The clamped-clamped and clamped-pinned boundary conditions are explored and the results with the 4th order and the 6th order of convergence are presented. The results are found to be in good agreement with the corresponding results of the Ritz method. The proposed approach can be considered as the principal improvement of the widely used Haar wavelet method providing the same accuracy with the several magnitudes lower mesh. Thus, the higher order Haar wavelet method has reduced the computational cost in comparison with the widely used Haar wavelet method since the computational complexity of both methods is determined by the mesh used. In the case of the fixed equal mesh used for both methods, the higher order Haar wavelet method results in the several magnitudes lower absolute error without a remarkable increase in computational complexity. The cost needed to pay for higher accuracy is hidden in a certain increase in the implementation complexity compared with the widely used Haar wavelet method.
\end{abstract}

Key words: higher order Haar wavelet method, tapered Timoshenko beam, free vibration.

\section{INTRODUCTION}

Development and adaptation of computational methods and mathematical modelling techniques are rapidly evolving research areas with the main focus on finding more accurate, less time-consuming, and simpler approximations.

The Haar wavelet method (HWM) was first introduced in [1-2]. According to Chen and Hsiao's approach, the highest order of derivatives included in a differential equation is expanded into a series of Haar functions [1-2]. This method is applied to solving differential and integro-differential equations covering applications in various research areas such as engineering, natural sciences, etc. [3-9]. Furthermore, this method is used as a numerical solution to linear and nonlinear delay differential equations [10], and space derivatives are obtained through the Haar wavelet collocation method to solve 1D and 2D cubic nonlinear Schrodinger equations [11]. In [12] the accuracy and convergence results of the HWM are presented. Based on the obtained

\footnotetext{
* Corresponding author, marmar.mehrparvar@taltech.ee
} 
results, it can be concluded that despite its simple implementation, the HWM needs refinement in order to compete with such widely used numerical methods as the finite difference method and the differential quadrature method.

Recently, the higher order Haar wavelet method (HOHWM) was introduced in [13] in order to improve the accuracy and convergence of the previously proposed Haar wavelet method. The HOHWM has been applied with success to solving differential equations, vibration, and buckling response of beams [14-18]. Theoretical and numerical analyses of the free and forced vibration of homogeneous and functionally graded Timoshenko beams have been performed [19-22]. In the case of tapered beams, many approaches have been used for analysing the Timoshenko beam that has a non-uniform cross-section [23-26].

The HOHWM is applied with success to the analysis of plate and shell structures using Euler-Bernoulli and zig-zag theories. In this paper the HOHWM approach is adapted to the Timoshenko beam theory.

\section{HOHWM APPROACH TO FREE VIBRATION ANALYSIS OF THE TIMOSHENKO BEAM}

In this section, the formulation of the free vibration of the tapered Timoshenko beam and boundary conditions are introduced.

\subsection{Free vibration of the Timoshenko beam}

A schematic view of the Timoshenko beam with a non-uniform cross-section along the length, $x$-direction, is shown in Fig. 1.

Herein, free vibration of homogeneous tapered Timoshenko beams has been investigated. The material properties of the beams are assumed to be constant. Firstly, the cross-sectional area $A(x)$ and the moment of inertia $I(x)$ are presented as

$$
A(x)=A_{0}\left(1-\frac{c x}{L}\right), I(x)=I_{0}\left(1-\frac{c x}{L}\right)^{3}, \quad x \in[0, L],
$$

where $A_{0}$ and $I_{0}$ are the area and the moment of inertia at the base of the beam, respectively. $L$ is the length of the beam, $E$ denotes Young's modulus, $G$ refers to shear modulus, $\rho$ represents mass density, and $k$ is the shear correction factor which is chosen to be $5 / 6$. For the described Timoshenko beam, the basic governing differential equations for transverse vibration of the tapered beam can be presented as

$$
\begin{gathered}
\frac{\partial}{\partial x}\left(E I(x) \frac{\partial \varphi}{\partial x}\right)+\kappa G A(x)\left(\frac{\partial w}{\partial x}-\varphi\right)-\rho I \frac{\partial^{2} \varphi}{\partial t^{2}}=0 \\
\frac{\partial}{\partial x}\left[\kappa G A(x)\left(\frac{\partial w}{\partial x}-\varphi\right)\right]-\rho A \frac{\partial^{2} w}{\partial t^{2}}=0
\end{gathered},
$$

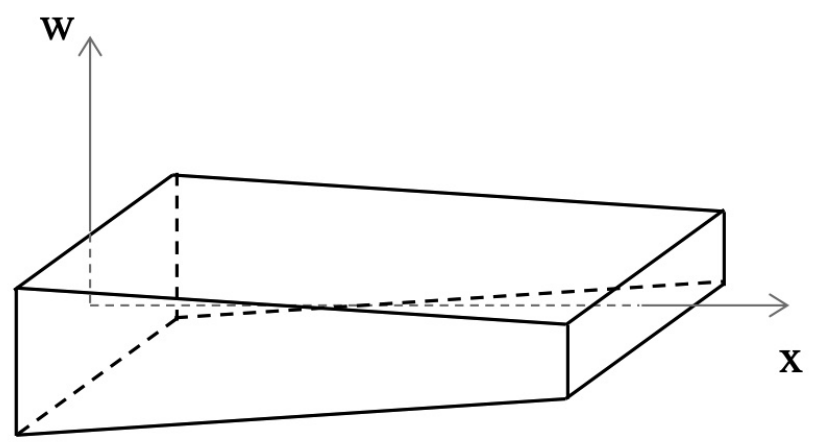

Fig. 1. Schematic view of a tapered beam. 
where $w$ and $\varphi$ are the transverse deflection and rotation of the cross-section, respectively. The bending moment $M$ and the shear force $Q$ at any cross-section can be read as

$$
M=E I(x) \frac{\partial \varphi}{\partial x}, \quad Q=k G A(x)\left(\frac{\partial w}{\partial x}+\varphi\right) .
$$

The boundary conditions for the beam can be expressed

$$
\begin{aligned}
& \text { for the clamped edge as: } w=0, \quad \varphi=0, \\
& \text { for the pinned edge as: } w=0, \quad M=0 .
\end{aligned}
$$

\subsection{Higher order Haar wavelet method}

The higher order Haar wavelet method (HOHWM) is developed as an improvement of the widely used Haar wavelet method (HWM) [13].

The $n$-th order ordinary differential equation, in general, can be presented as

$$
G\left(x, u, u^{\prime}, u^{\prime \prime}, \ldots u^{(n-1)}, u^{(n)}\right)=0,
$$

where $n$ represents the order of the highest derivative involved in the differential equation. In the HOHWM, in comparison to the Haar wavelet method, the order of expansion is increased by $2 s$, Eq. (6). Based on the Haar wavelet, the expansion is presented as

$$
f(x)=\frac{d^{n+2 s} u(x)}{d x^{n+2 s}}=\sum_{i=1}^{\infty} a_{i} h_{i}(x), s=1,2, \ldots,
$$

in which $h_{i}(x)$ is the Haar function [18]

$$
h_{i}(x)=\left\{\begin{array}{ccc}
1 & \text { for } & x \in\left[\xi_{1}(i), \xi_{2}(i)\right) \\
-1 & \text { for } & x \in\left[\xi_{2}(i), \xi_{3}(i)\right), \\
0 & \text { elsewhere } &
\end{array}\right.
$$

where $i=m+k+1, m=2^{j}$ is a maximum number of square waves arranged in the interval $[A, B]$ and the parameter $k$ indicates the location of the particular square wave [18]

$$
\begin{gathered}
\xi_{1}(i)=A+2 k \mu \Delta x, \quad \xi_{2}(i)=A+(2 k+1) \mu \Delta x, \quad \xi_{3}(i)=A+2(k+1) \mu \Delta x, \\
\mu=M / m, \quad \Delta x=(B-A) /(2 M) .
\end{gathered}
$$

The integrals of the Haar functions (7) of order $n$ can be expressed as [13]

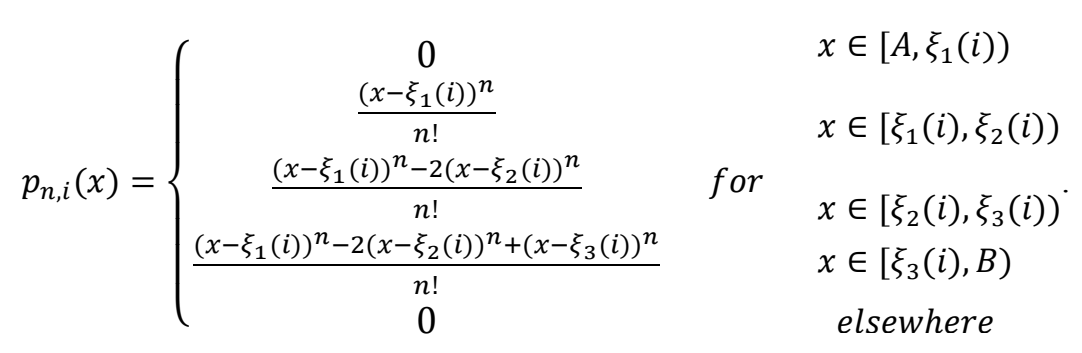

The differential equation can be satisfied in selected uniform grid points

$$
x_{i L}=\frac{i}{2 M}, x_{i R}=1-\frac{i}{2 M}, i=0, \ldots, s-1,
$$


where $L$ and $R$ are the added collocation points on the left and right boundary, respectively. Then the numerical order of the convergence of the method can be estimated by

$$
\text { Convergence rate }=\frac{\log \left(\frac{F_{i-1}-F_{R e f}}{F_{i}-F_{R e f}}\right)}{\log (2)},
$$

where $F_{\text {Ref }}$ is the existing solution, which in the current solution is obtained from the Ritz method [21].

\section{NUMERICAL RESULTS}

In order to showcase the accuracy of the formulation proposed above, the values of natural frequencies of the Timoshenko beam under two arbitrary boundary conditions are presented. Table 1 presents the effect of

Table 1. Effect of taper ratio on non-dimensional natural frequencies of the C-C Timoshenko beam

\begin{tabular}{|c|c|c|c|c|c|c|c|c|c|c|}
\hline & \multirow[t]{2}{*}{$\mathrm{N}$} & \multicolumn{3}{|c|}{ HWM } & \multicolumn{3}{|c|}{ HOHWM 4th } & \multicolumn{3}{|c|}{ HOHWM 6th } \\
\hline & & Frequency & A. error & $\begin{array}{c}\text { Conv. } \\
\text { rate }\end{array}$ & Frequency & A. error & $\begin{array}{c}\text { Conv. } \\
\text { rate }\end{array}$ & Frequency & A. error & $\begin{array}{c}\text { Conv. } \\
\text { rate }\end{array}$ \\
\hline \multirow[t]{8}{*}{$c=0$} & 4 & 13.96275845 & $1.28 \mathrm{e}-01$ & & 13.84197845 & $7.22 \mathrm{e}-03$ & & 13.83477975 & $2.13 \mathrm{e}-05$ & \\
\hline & 8 & 13.86655612 & $3.18 \mathrm{e}-02$ & 2.0091 & 13.83519214 & $4.34 \mathrm{e}-04$ & 4.0576 & 13.83476001 & $1.56 \mathrm{e}-06$ & 5.4358 \\
\hline & 16 & 13.84269132 & $7.93 e-03$ & 2.003 & 13.83478525 & $2.68 \mathrm{e}-05$ & 4.0146 & 13.83475854 & $8.43 \mathrm{e}-08$ & 5.7522 \\
\hline & 32 & 13.83674066 & $1.98 \mathrm{e}-03$ & 2.0007 & 13.83476012 & $1.67 \mathrm{e}-06$ & 4.0036 & 13.83475846 & $1.51 \mathrm{e}-09$ & 5.9467 \\
\hline & 64 & 13.83525392 & $4.95 \mathrm{e}-04$ & 2.00019 & 13.83475856 & $1.04 \mathrm{e}-07$ & 4.0009 & 13.83475846 & $7.71 \mathrm{e}-10$ & 5.9955 \\
\hline & 128 & 13.83488232 & $1.24 \mathrm{e}-04$ & 2.00004 & 13.83475846 & $6.53 \mathrm{e}-09$ & 4.0002 & 13.83475845 & $4.08 \mathrm{e}-11$ & 5.9999 \\
\hline & 256 & 13.83478942 & $3.10 \mathrm{e}-05$ & 2.00001 & 13.83475845 & $4.08 \mathrm{e}-10$ & 4.0000 & 13.83475845 & $1.40 \mathrm{e}-13$ & 6.0000 \\
\hline & \multicolumn{10}{|c|}{ Existing result $=13.834758$} \\
\hline \multirow[t]{8}{*}{$c=0.4$} & 4 & 13.38213007 & $9.60 \mathrm{E}-01$ & & 12.42216412 & $3.56 \mathrm{E}-02$ & & 12.42216313 & $4.40 \mathrm{E}-03$ & \\
\hline & 8 & 12.51071171 & $8.85 \mathrm{E}-02$ & 2.0154 & 12.45779287 & 7.62E-03 & 4.3451 & 12.42655937 & 7.71E-04 & 6.0527 \\
\hline & 16 & 12.43177774 & $9.61 \mathrm{E}-03$ & 2.0095 & 12.42293499 & $7.72 \mathrm{E}-04$ & 4.0623 & 12.42217245 & $9.32 \mathrm{E}-06$ & 6.0129 \\
\hline & 32 & 12.42292193 & $7.59 \mathrm{E}-04$ & 2.0037 & 12.42221943 & $5.63 \mathrm{E}-05$ & 4.0103 & 12.42216313 & $4.41 \mathrm{E}-07$ & 6.0099 \\
\hline & 64 & 12.42223492 & $7.18 \mathrm{E}-05$ & 2.0018 & 12.42978489 & $9.92 \mathrm{E}-07$ & 4.0096 & 12.42293432 & $4.36 \mathrm{E}-09$ & 6.0042 \\
\hline & 128 & 12.42218071 & $1.76 \mathrm{E}-05$ & 2.0008 & 12.42216317 & 4.02E-08 & 4.0073 & 12.42216357 & $7.28 \mathrm{E}-10$ & 6.0017 \\
\hline & 256 & 12.42216626 & $3.13 \mathrm{E}-06$ & 2.0003 & 12.42216313 & 4.39E-09 & 4.0023 & 12.42216313 & $2.71 \mathrm{E}-11$ & 6.0009 \\
\hline & \multicolumn{10}{|c|}{ Existing result $=12.422163$} \\
\hline \multirow[t]{8}{*}{$c=0.8$} & 4 & 10.7701461 & $1.04 \mathrm{E}+00$ & & 9.738846102 & $1.17 \mathrm{E}-02$ & & 9.727997702 & $8.52 \mathrm{E}-04$ & \\
\hline & 8 & 10.2871461 & $5.60 \mathrm{E}-01$ & 2.0994 & 9.727886102 & 7.40E-04 & 4.0807 & 9.727181202 & $3.51 \mathrm{E}-05$ & 6.0698 \\
\hline & 16 & 9.782096102 & $5.50 \mathrm{E}-02$ & 2.0848 & 9.727219602 & $7.35 \mathrm{E}-05$ & 4.0713 & 9.727147068 & $9.66 \mathrm{E}-07$ & 6.0695 \\
\hline & 32 & 9.728230102 & $1.08 \mathrm{E}-03$ & 2.0631 & 9.727157102 & $1.10 \mathrm{E}-05$ & 4.0466 & 9.727146185 & $8.28 \mathrm{E}-08$ & 6.0606 \\
\hline & 64 & 9.727253202 & $1.07 \mathrm{E}-04$ & 2.0480 & 9.727151332 & $5.23 \mathrm{E}-06$ & 4.0402 & 9.727146103 & $6.74 \mathrm{E}-10$ & 6.0326 \\
\hline & 128 & 9.727156532 & $1.04 \mathrm{E}-05$ & 2.0279 & 9.727146886 & 7.84E-07 & 4.0198 & 9.727146102 & $4.75 \mathrm{E}-11$ & 6.0050 \\
\hline & 256 & 9.727147652 & $1.55 \mathrm{E}-06$ & 2.0051 & 9.727146151 & $4.90 \mathrm{E}-08$ & 4.0074 & 9.727146102 & $6.84 \mathrm{E}-12$ & 6.0007 \\
\hline & & & & & & & & & & \\
\hline
\end{tabular}

A. error - Absolute error 
Table 2. Effect of boundary conditions on non-dimensional natural frequencies of the tapered Timoshenko beam $(c=0.2)$

\begin{tabular}{|c|c|c|c|c|c|c|c|c|c|c|}
\hline & \multirow[t]{2}{*}{$\mathrm{N}$} & \multicolumn{3}{|c|}{ HWM } & \multicolumn{3}{|c|}{ HOHWM 4th } & \multicolumn{3}{|c|}{ HOHWM 6th } \\
\hline \multirow{8}{*}{ C-P } & & Frequency & A. error & $\begin{array}{c}\text { Conv. } \\
\text { rate }\end{array}$ & Frequency & A. error & $\begin{array}{c}\text { Conv. } \\
\text { rate }\end{array}$ & Frequency & A. error & $\begin{array}{c}\text { Conv. } \\
\text { rate }\end{array}$ \\
\hline & 4 & 12.48688739 & $1.80 \mathrm{E}+00$ & & 11.05355589 & $3.67 \mathrm{E}-01$ & & 10.77030682 & $8.34 \mathrm{E}-02$ & \\
\hline & 8 & 11.05808739 & $3.70 \mathrm{E}-01$ & 2.3120 & 10.73676607 & $6.99 \mathrm{E}-02$ & 4.8521 & 10.68746912 & $5.82 \mathrm{E}-04$ & 7.6790 \\
\hline & 16 & 10.75601079 & $6.91 \mathrm{E}-02$ & 2.0624 & 10.6877406 & $8.53 \mathrm{E}-03$ & 4.0629 & 10.68692751 & $4.01 \mathrm{E}-05$ & 6.6293 \\
\hline & 32 & 10.69501206 & $8.12 \mathrm{E}-03$ & 2.0039 & 10.6869284 & 4.10E-04 & 4.0132 & 10.68688961 & $2.22 \mathrm{E}-06$ & 6.0872 \\
\hline & 64 & 10.68781264 & $9.25 \mathrm{E}-04$ & 2.0007 & 10.68688976 & $2.37 \mathrm{E}-05$ & 4.0083 & 10.6868877 & $3.06 \mathrm{E}-07$ & 6.0034 \\
\hline & 128 & 10.68715151 & $2.64 \mathrm{E}-04$ & 2.0003 & 10.68688778 & $3.94 \mathrm{E}-06$ & 4.0019 & 10.6868874 & $9.28 \mathrm{E}-09$ & 6.0012 \\
\hline & 256 & 10.68695081 & $6.30 \mathrm{E}-05$ & 2.00002 & 10.6868874 & 7.31E-07 & 4.0005 & 10.68688739 & $2.79 \mathrm{E}-10$ & 6.0008 \\
\hline \multirow{9}{*}{$\mathrm{C}-\mathrm{C}$} & \multicolumn{10}{|c|}{ Existing result $=10.68689$} \\
\hline & 4 & 14.32226684 & $1.10 \mathrm{E}+00$ & & 13.26456684 & $4.23 \mathrm{E}-02$ & & 13.22543684 & $3.17 \mathrm{E}-03$ & \\
\hline & 8 & 13.95226684 & $7.30 \mathrm{E}-01$ & 2.0906 & 13.22523684 & $2.97 \mathrm{E}-03$ & 4.1523 & 13.22233484 & $6.80 \mathrm{E}-05$ & 6.0228 \\
\hline & 16 & 13.28756684 & $6.53 \mathrm{E}-02$ & 2.0746 & 13.22246484 & $1.98 \mathrm{E}-04$ & 4.0945 & 13.22226727 & 4.35E-07 & 6.0197 \\
\hline & 32 & 13.22697684 & $4.71 \mathrm{E}-03$ & 2.0595 & 13.22227401 & 7.17E-06 & 4.0840 & 13.22226686 & $1.76 \mathrm{E}-08$ & 6.0131 \\
\hline & 64 & 13.22245884 & $1.92 \mathrm{E}-04$ & 2.0164 & 13.22226732 & 4.83E-07 & 4.0570 & 13.22226684 & $6.23 \mathrm{E}-09$ & 6.0109 \\
\hline & 128 & 13.22232314 & $5.63 \mathrm{E}-05$ & 2.0117 & 13.22226737 & $5.34 \mathrm{E}-07$ & 4.0338 & 13.22226684 & $6.31 \mathrm{E}-10$ & 6.0072 \\
\hline & 256 & 13.22227227 & $5.43 \mathrm{E}-06$ & 2.0021 & 13.22226684 & 4.85E-09 & 4.0013 & 13.22226684 & $5.02 \mathrm{E}-11$ & 6.0020 \\
\hline & \multicolumn{10}{|c|}{ Existing result $=13.222267$} \\
\hline
\end{tabular}

taper ratio $(c)$ for the beam under clamped-clamped (C-C) boundary conditions. The results are compared with the existing results obtained from the Ritz method and alternative methods employed in [22,25].

As expected, for the beam with the taper ratio other than $c=0$, the non-dimensional natural frequency decreases for the higher value of $c$. Moreover, as it can be observed, the results of the higher order Haar wavelet method prove that in the case of the 4th and the 6 th order of convergence, the absolute error reduces much faster by increasing the number of terms in the Haar wavelet method. This matter could be essential in the case of more complex problems, thus the accurate result can be obtained faster and with a smaller number of terms.

The effect of boundary conditions is shown in Table 2. For the tapered Timoshenko beam $(c=0.2)$, the results of two boundary conditions - clamped-clamped (C-C) and clamped-pinned (C-P) - are produced, which prove the above-mentioned point for the higher order Haar wavelet method. In the future study, the HOHWM is planned to be applied to design optimization of plate and shell structures [27-31].

\section{CONCLUSIONS}

During the last two years, the HOHWM has been applied with success to the analysis of plate and shell structures by using Euler-Bernoulli and zig-zag theories. In the current study, the HOHWM is extended to the vibration analysis of Timoshenko beams. The solution has been used to analyse the beam under two boundary conditions, clamped-clamped and clamped-pinned. The results for beams with different taper ratios prove that the higher order Haar wavelet method is accurate, and for the versions with the higher order of convergence (4th and 6th order) the absolute error drops extremely fast. These results can be translated to a faster, simpler, and more accurate solution for other structural analyses where the analytical solution is difficult to obtain. 


\section{ACKNOWLEDGEMENTS}

The study was supported by the Estonian Centre of Excellence in Zero Energy and Resource Efficient Smart Buildings and Districts, ZEBE, TK146 funded by the European Regional Development Fund (grant 20142020.4.01.15-0016); Smart Industry Centre (SmartIC) funded by the Estonian Research Council TT2; Estonian Research Council project MOBJD704 "Development of numerical methods for analysis of advanced composite and nanostructures"; AR20013 Smart City Centre of Excellence (1.01.2020-31.08.2023). The publication costs of this article were covered by the Estonian Academy of Sciences.

\section{REFERENCES}

1. Chen, C. F. and Hsiao, C. H. Haar wavelet method for solving lumped and distributed-parameter systems. IEE Proc. Control Theory Appl., 1997, 144(1), 87-94.

2. Hsiao, C. H. State analysis of the linear time delayed systems via Haar wavelets. Math. Comput. Simul., 1997, 44(5), 457-470.

3. Lepik, Ü. Buckling of elastic beams by the Haar wavelet method. Estonian J. Eng., 2011, 17(3), 271-284.

4. Lepik, Ü. Numerical solution of differential equations using Haar wavelets. Math. Comput. Simul., 2005, 68(2), 127-143.

5. Lepik, Ü. Numerical solution of evolution equations by the Haar wavelet method. Appl. Math. Comput., 2007, 185(1), 695-704.

6. Hein, H. and Feklistova, L. Computationally efficient delamination detection in composite beams using Haar wavelets. Mech. Syst. Signal Process., 2011, 25(6), 2257-2270.

7. Hein, H. and Feklistova, L. Free vibrations of non-uniform and axially functionally graded beams using Haar wavelets. Eng. Struct., 2011, 33(12), 3696-3701.

8. So, S.-R., Yun, H., Ri, Y., O, R. and Yun, Y.-I. Haar wavelet discretization method for free vibration study of laminated composite beam under generalized boundary conditions. J. Ocean Eng. Sci., 2021, 6(1), 1-11.

9. Aziz, I. and Šarler, B. The numerical solution of second-order boundary-value problems by collocation method with the Haar wavelets. Math. Comput. Model., 2010, 52(9-10), 1577-1590.

10. Aziz, I. and Amin, R. Numerical solution of a class of delay differential and delay partial differential equations via Haar wavelet. Appl. Math. Model., 2016, 40(23-24), 10286-10299.

11. Pervaiz, N. and Aziz, I. Haar wavelet approximation for the solution of cubic nonlinear Schrodinger equations. Physica A, $2020, \mathbf{5 4 5}, 123738$.

12. Majak, J., Shvartsman, B., Karjust, K., Mikola, M., Haavajõe, A. and Pohlak, M. On the accuracy of the Haar wavelet discretization method. Compos. B. Eng., 2015, 80, 321-327.

13. Majak J., Pohlak, M., Karjust, K., Eerme, M., Kurnitski, J. and Shvartsman, B. S. New higher order Haar wavelet method: Application to FGM structures. Compos. Struct., 2018, 201, 72-78.

14. Majak, J., Pohlak, M., Eerme, M. and Shvartsman, B. Solving ordinary differential equations with higher order Haar wavelet method. AIP Conf. Proc., 2019, 2116, 330002.

15. Majak, J., Shvartsman, B., Ratas, M., Bassir, D., Pohlak, M., Karjust, K. and Eerme, M. Higher-order Haar wavelet method for vibration analysis of nanobeams. Mater. Today Commun., 2020, 25, 101290.

16. Jena, S. K., Chakraverty, S. and Malikan, M. Implementation of Haar wavelet, higher order Haar wavelet, and differential quadrature methods on buckling response of strain gradient nonlocal beam embedded in an elastic medium. Eng. Comput., 2021, 37(2), 1251-1264.

17. Ratas, M., Salupere, S. and Majak, J. Solving nonlinear PDEs using the higher order Haar wavelet method on nonuniform and adaptive grids. Math. Model. Anal., 2021, 26(1), 147-169.

18. Sorrenti, M., Di Sciuva, M., Majak, J. and Auriemma, F. Static response and buckling loads of multilayered composite beams using the refined zigzag theory and higher-order Haar wavelet method. Mech. Compos. Mater., 2021, 57(1), 1-18.

19. Majkut, L. Free and forced vibrations of Timoshenko beams described by single difference equation. J. Theor. Appl. Mech., 2009, 47(1),193-210.

20. Shahba, A., Attarnejad, R., Marvi, M. T. and Hajilar, S. Free vibration and stability analysis of axially functionally graded tapered Timoshenko beams with classical and non-classical boundary conditions. Compos. B. Eng., 2011, 42(4), 801-808.

21. Zhou, D. and Cheung, Y. K. Vibrations of tapered Timoshenko beams in terms of static Timoshenko beam functions, J. Appl. Mech., 2001, 68(4), 596-602.

22. Pradhan, K. K. and Chakraverty, S. Free vibration of Euler and Timoshenko functionally graded beams by Rayleigh-Ritz method. Compos. B. Eng., 2013, 51,175-184.

23. Attarnejad, R., Semnani, S. J. and Shahba, A. Basic displacement functions for free vibration analysis of non-prismatic Timoshenko beams. Finite Elem. Anal. Des., 2010, 46(10), 916-929.

24. Sohani, F. and Eipakchi, H. R. Analytical solution for modal analysis of Euler-Bernoulli and Timoshenko beam with an arbitrary varying cross-section. Math. Model. Eng., 2018, 4(3), 164-174. 
25. Tang, A.-Y., Wu, J.-X., Li, X.-F. and Lee, K. Y. Exact frequency equations of free vibration of exponentially non-uniform functionally graded Timoshenko beams. Int. J. Mech. Sci., 2014, 89, 1-11.

26. Huang, Y., Yang, L.-E. and Luo, Q.-Z. Free vibration of axially functionally graded Timoshenko beams with non-uniform crosssection. Compos. B. Eng., 2013, 45(1), 1493-1498.

27. Guessasma, S. and Bassir, D. Optimization of the mechanical properties of virtual porous slids using a hybrid approach. Acta Mater, 2010, 58(2), 716-725.

28. Guessasma, S. and Bassir, D. Identification of mechanical properties of biopolymer composites sensitive to interface effect using hybrid approach. Mech. Mater, 2010, 42(3), 344-353.

29. Snatkin, A., Eiskop, T., Karjust, K. and Majak, J. Production monitoring system development and modification. Proc. Estonian Acad. Sci., 2015, 64(4S), 567-580.

30. Guessasma, S., Bassir, D. and Hedjazi, L. Influence of interphase properties on the effective behaviour of a starch-hemp composite. Mater. Des., 2015, 65, 1053-1063.

31. Abouzaid, K., Bassir, D., Guessasma, S. and Yue, H. Modelling the process of fused deposition modelling and the effect of temperature on the mechanical, roughness, and porosity properties of resulting composite products. Mech. Compos. Mater., 2021, 56, 805-816.

\section{Muutuva ristlõikega Timoshenko tala vabavõnkumiste analüüs kõrgemat järku Haari lainikute meetodi abil}

\section{Marmar Mehrparvar, Jüri Majak, Kristo Karjust ja Mustafa Arda}

Viimase kahe aasta jooksul on rakendatud kõrgemat järku Haari lainikute meetodit plaatide ja koorikute analüüsiks, kasutades peamiselt Euler-Bernoulli teooriat, ühes artiklis ka zig-zag teooriat. Käesolevas töös on laiendatud kõrgemat järku Haari lainikute meetod Timoshenko tala vabavõnkumiste analüüsiks. Töös on kasutatud jäik-jäik ja jäik-vaba (vaba toetus) rajatingimusi. Analüüsitud on erivate ristlõike muutumise koefitsentidele vastavaid lahendusi. Kõrgemat järku Haari lainikute meetod osutus täpseks ja kiireks nii 4. kui 6. järku koonduvuse korral (koonduvuse järk on määratud meetodi parameetriga). Saadud tulemused on üldistatavad laiema plaatide/koorikute vabavõnkumisi käsitlevate ülesannete klassi jaoks, kattes ka juhtusid, kus analüütiline lahend puudub. Saadud tulemused on kooskõlas laiemalt kasutatava Haari lainikute meetodi ja Ritzi meetodi abil saadud tulemustega. Kõrgemat järku Haari lainikute meetodit võib vaadelda kui Haari lainikute meetodi edasiarendust, mis tagab kõrgemat järku koonduvuskiiruse ja väiksema absoluutse vea. 